\title{
12
}

\section{Factories of Turkic Muslim internment ${ }^{*}$}

\author{
Darren Byler
}

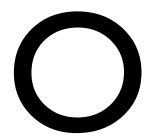

n 3 November 2018, Yerzhan Qurban, a middle-aged Kazakh man from a small village 50 kilometres from the city of Ghulja in the Xinjiang Uyghur Autonomous Region, was released from the camp where he had been held for nine months. He thought perhaps now he would be free to return to his former life as an immigrant in Kazakhstan. Yet, just a few days later, he was sent to an industrial park in Ghulja to work in a glove factory. For the next 53 days, he experienced life in an internment factory that was built to 'raise the quality' (提高素 质) of minority workers.

Yerzhan had been detained soon after he returned to China from Kazakhstan to seek medical treatment for his daughter and care for his ailing mother in early 2018. In a 2019 interview with the German magazine Die Zeit, he said:

On the evening of 8 February 2018, they picked me up in a minibus. It was already dark and they put black plastic sacks over our heads and handcuffs on our hands. There were five young men from my village with me on the minibus. The room in which I had to stay for the next nine months was 5 metres by 5 metres and located on the third floor. On the door, a sign said 'No. 12'. Our floor alone accommodated $260 \mathrm{men}$. In my room, we were 12. Later I heard that there had been more than 10,000 men detained in our camp. (Die Zeit 2019)

Yerzhan was unsure exactly where the camp was located. It may have been the one built in the fields on the outskirts of the city, just 7 kilometres from the industrial park where he was later forced to work (Die Zeit 2019).

*This chapter is based on an article published in the news journal SupChina on 4 September 2019 titled 'How Companies Profit from Forced Labor in Xinjiang' (available from: supchina. com/2019/09/04/how-companies-profit-from-forced-labor-in-xinjiang). 
As is often reported by former detainees, conditions in the camp were appalling. Describing the circumstances of his detention, Yerzhan said:

\begin{abstract}
The toilet was a bucket by the window, there was no running water. In the daytime, we were sitting in rows on our plastic stools. The food was handed to us through an opening in the door. At $7 \mathrm{am}$, we had to sing the Chinese national anthem and then we had three minutes for breakfast. Afterwards, we learned Chinese until 9pm. Our teachers were Kazakhs or Uyghurs. We were watched by four cameras in our room which ensured that we didn't talk to each other. Those who spoke anyway were handcuffed and had to stand by the wall. 'You don't have the right to talk, because you are not humans,' said the guards. 'If you were humans, you wouldn't be here.' (Die Zeit 2019)
\end{abstract}

Yerzhan said he still does not know why he was taken. Like others detained in Ghulja, his internment was likely because he possessed a passport and had travelled to Kazakhstan-one of 26 Muslim-majority countries on a Chinese state watchlist (see HRW 2019). Over time, the gruelling routine began to change his mental state. He said: 'The first two months, I thought of my wife Maynur and my three children. Sometime later, I only thought about food' (Die Zeit 2019).

About the time Yerzhan was reduced to thinking about his bodily survival, in May 2018, Pan Daojin, the Front Commander and Party Secretary of Yili prefecture, arrived to inspect a newly built industrial park on the other side of town (The Times of Nantong Aiding Xinjiang 2018). He came with a delegation from Jiangsu tasked with providing industrial 'aid' to Xinjiang. Pan, who is also from Jiangsu, was appointed to his position in December 2016, just as the mass detentions of the reeducation system began. During the inspection of the new industrial park, he 'fully affirmed the achievements' of the business leaders from Nantong City in Jiangsu who had funded it. The delegation showed off the new factory of the Jiangsu-based Solamoda Garment Group-a company that partners with Forever 21 and other international brands. They also visited the highly productive glove factory to which Yerzhan would be eventually assigned. This factory was managed by employees of the Luye Shuozi Island Trading Company, a manufacturer based in Baoding City, Hebei Province. 
According to the general manager of the glove factory, Wang Xinghua, speaking in a state TV interview released in December 2018: 'With the support of the government, we have already recruited more than 600 people' (Ili Television 2018). One of these 600 government 'recruits' was Yerzhan, who had arrived from the camp less than a month before. General Manager Wang went on to say that since the founding of the new factory in 2017, 'We have generated more than US\$6 million in sales. We plan to reach 1,000 workers by the end of this year. We plan to provide jobs to 1,500 people by the end of 2019.' In fact, the glove factory in Ghulja has now far surpassed the capacity of its parent factory, which back in Hebei has less than 200 employees (Alibaba 2019). Moving manufacturing to Xinjiang made economic sense for the company, which sold 96 per cent of its leather gloves across the border in Russia and Eastern Europe.

But there were other reasons why exponential growth was so easy. Since 2018, the state has provided subsidies to build factories in and ship goods from Xinjiang. Construction of the factories was often funded by local governments in eastern China as part of a 'pairing assistance' (配 对与援助) program. Up to 4 per cent of new factories' sales volume was subsidised to cover shipping expenses from the new location (People's Government of XUAR 2018). Most importantly, as in every county in Xinjiang, there was a standing labour reserve of tens of thousands of desperate, traumatised detainees like Yerzhan in nearby camps.

\section{A carrier of the economy}

Since 2017, factories have flocked to Xinjiang to take advantage of the newly built industrial parks associated with the reeducation camp system and the cheap labour and subsidies that accompany them. In fact, in late 2018, the primary development ministry for the region, the Xinjiang Development and Reform Commission, circulated a statement saying the camps or 'vocational skills education and training centres' (教育培 训中心) had become a 'carrier' (载体) of the economy (XJDRC 2018). Because of this system, Xinjiang had attracted 'significant investment and construction from coast-based Chinese companies'. Since China sources more than 80 per cent of its cotton from Xinjiang, there was a special emphasis placed on Chinese textile and garment-related industries (Gro Intelligence 2019). In an effort motivated at least in part by rising labour costs among Han migrant workers on the east coast, the state plans to move more than one million textile and garment industry jobs to the 
Xinjiang region by 2023 (Patton 2016). If it succeeds, it will mean that as many as one in every 11 textile and garment industry jobs in China will be in Xinjiang (ILO 2014). The 1,500 jobs at the glove factory in Ghulja are part of that number.

There are three primary tracks through which Uyghurs and other Turkic Muslims are involuntarily assigned to work in the newly built factories as part of the reeducation labour regime. First, many detainees in camps are placed in factories inside or adjacent to camps. They work inside the same camp space in which they are held at night. Second, some new industrial parks built in regional centres host a mix of former detainees and 'rural surplus labourers' who are not former detainees. These surplus labourers are chosen from self-employed populations of rural farmers and periurban Kazakhs and Uyghurs who previously found contingent work in heritage trades and service industries. In a new carceral instantiation of what Chris Smith and Pun Ngai (2006) refer to as the dormitory labour regime' used to surveil and exploit migrant workers in eastern China, the former detainees who join these surplus labourers in the urban industrial parks are often held in locked dormitories at night, as in the case of Yerzhan. Some 'surplus labourers'-like migrant workers in eastern China-are permitted to return to their own homes at night or to stay in freely chosen accommodation in the regional centre. Third, newly built county-level and smaller-scale 'satellite factories' (卫星工厂) in rural areas host Uyghur workers near their homes. These worker populations of mainly women with young children are assigned by local village and township-level authorities to work while their children are in daycare facilities; their husbands work in the city or are detained in camps. While there are different levels of coercion in these tracks, all three result in forms of family separation and dependence on the state and private industry proxies for training and discipline in Chinese-speaking environments.

In all cases, Turkic Muslim detainees are forcibly assigned to these positions. As documents used by 'neighbourhood watch unit' (社区) and 'village-level work brigade' (大队) workers note, refusing 'poverty alleviation' (扶贫) schemes一 - a widely used euphemism for assigned factory work and other forms of 'coercive assistance' (Pan 2020)-is regarded as a sign of untrustworthiness and religious extremism (Turkistan Press 2018). These grassroots-level state workers who partner with police stations and private and state-owned enterprises to implement the campaign are charged with providing employees from populations within their jurisdictions. They often accompany workers to the factories 
and, at times, act as intermediaries between factory management and the workers. They also enforce discipline on the factory floor and, in some cases, in dormitories. In a radical contravention of the supposed 'freedom' associated with market-based contract law, state authorities assume the only reason a Muslim worker may not want to be separated from their families and work for low wages in a Han-managed factory is because of their aversion to contact with non-Muslims. Forcing Uyghurs and Kazakhs to work in a Chinese-speaking environment can then be framed by state workers and employers as liberating them from their 'native' way of life and traditions. This framing elides the process of state and market dependence that is created by dispossessing Uyghurs and Kazakhs of what Marx (1978) would describe as their own 'means of production' and the radical forms of unfreedom that are produced by forced labour in an alien environment.

The glove factory to which Yerzhan was sent appears to have a mix of both former detainees and involuntarily assigned 'surplus workers'. Many, like Yerzhan, arrived in the factory after briefly being released from the camp. Yet, according to a state report, it appears that more than 1,800 others were sent to work in the industrial park in mid-2017, long before the first detainees were transferred from the camps (Zero Distance Yining 2017). According to Yerzhan and a second worker named Gulzira Auelkhan, whom I interviewed, these early arrivals were 'track two' underemployed rural workers who were determined to be part of the 'normal' population and were assigned to work without first being placed in a camp.

\section{Unfree labour}

Several months before Yerzhan arrived at the glove factory, another Kazakh detainee was also transferred from a nearby reeducation camp to work there. Before arriving, Gulzira, a 39-year-old mother of a toddler whom she left with her husband back in Kazakhstan, had endured 15 months of horrific abuse in crowded cells with 18 to 60 other detainees, most of whom were Uyghur (Xinjiang Victims Database 2019). Detainees in her cell were repeatedly shocked in the head with electric batons if they used the bathroom for longer than two minutes. Their closely cropped hair masked some of the visible bruising. Detainees were given dye to darken their hair and scalp before higher-level officials visited the camp (Azat 2019). They were told to smile during the inspections. 
Due to the relatively low level of her perceived 'pre-criminal offences'according to documents supplied to the United Nations by the Chinese Government, many detainees in the camps had not actually committed crimes (UN 2019) - Gulzira was placed in a camp that had the least amount of security. What had marked her as 'untrustworthy' was a previous visit to Kazakhstan and the fact she watched Turkish TV shows in which women wore hijabs. In her section of the camp, there was less of an emphasis on ideological retraining. Instead, the detainees studied Chinese all day, every day. Kazakh and Uyghur languages were not permitted.

Like Yerzhan, when Gulzira was released from the camp, she thought she may be given greater freedom. But within several days, a local village leader appeared with a document saying she must report for work at the glove factory. When she arrived at the plant, she recognised her new boss, General Manager Wang. She had seen him several times in the camp, on tours with camp officials. She surmised that he must have picked her to work in his factory while she was still in the camp. She was told that as a trainee she would be paid 600 yuan per month (approximately US\$100)-one-third of the 1,800-yuan state-mandated minimum wage in the region-for the first three months. She would also be paid a small amount, around 2 jiao (20 Chinese cents), per pair of gloves according to her 'efficiency'. She said: 'The most skilled worker could sew 60 pairs a day. I tried my best, but I could only sew 13 pairs' (Vanderklippe 2019). Since she did not have good eyesight, she found it impossible to improve her productivity. Speaking to Ben Mauk, she said:

In the end, I worked there for a month and a half. It was piecework. I earned one jiao for every glove I finished. All told, I made more than two thousand gloves and earned 220 yuan. So, you see, it was like slavery. (Xinjiang Victims Database 2019)

Although there was less security in the factory than in the camp, the detainees were not allowed to leave. In an interview I did with her in January 2020, months after she had fled across the Chinese border to Kazakhstan, Gulzira spoke of checkpoints at the entrance of the dormitory and factory where her ID and face were scanned. She said:

We would have our bodies and phones checked when we arrived, and in the middle of the day. When we were leaving for the dormitory at the end of the day they would check again, because they 
were worried we might take a [sewing] needle. After we got to know [the police contractors,] we asked them, 'Why are you still here watching us?'

While they never replied, she told me she knew the answer was that the security workers were monitoring whether the detainees were acting like submissive 'reeducated' industrial workers. She noted that, like every other Turkic Muslim she knew, her passport had been confiscated and travel beyond the parameters of their assigned locality-whether it was an industrial park or the relative freedom of a village-was not permitted. In addition, like most assigned workers, she had very little money with which to attempt to pay someone to smuggle her out. Life at the factory was better than life in the camp, but she understood that in the new space she was being asked to prove that she had become a truly reeducated industrial worker.

Outside the discipline of the factory and industrial park, the infrastructure of material walls continued to be a part of her life. Every night after work, she and other detainees were taken by bus to a makeshift dormitory around 3 kilometres away. In the dormitory, detainees were permitted to walk around the campus, but they were not permitted to leave the premises. According to reporting from The Globe and Mail, the workers 'received readings in the factory before work and, at day's end, 45-minute Chinese lessons in the dormitory, where they were watched at night by an official' (Vanderklippe 2019).

Both Yerzhan and Gulzira were permitted to visit relatives for several hours during one day on the weekend. A company bus would ferry them back and forth from the dormitory to their home villages. A month into their 'training', however, they found out that these trips were quite costly. Bosses at the factory, such as General Manager Wang, told them that because of the cost of the shuttle service and their food expenses, their 600-yuan salary would be slashed in half. Yerzhan later recalled: 'I worked on a production line for 53 days, earning 300 yuan in total.'

Government documents show that in Kashgar prefecture in 2018, 100,000 detainees were scheduled to move into and work in the newly built industrial parks and satellite factories (Kashgar Regional Administrative Office 2018). Other prefectures aimed for similar numbers. In Kashgar, for each detainee put to work, the factory owners would receive 5,000 yuan dispersed over three years. These subsidies were likely put in place to prevent the type of wage garnishment that Yerzhan and Gulzira 
experienced. However, since the factories function as an extension of the camp system, operating in a legal grey zone outside civil and human rights, prevention of worker abuse falls to the moral code of people like General Manager Wang. As an industrialist acting as a proxy for the carceral state, he knew just as well as Yerzhan or Gulzira that any complaint, any slowdown in production, could result in their replacement with other detainees. He could treat them in any way he wanted.

\section{Social implications of reeducation industrial parks}

Newly built industrial parks in northwestern China occupy a liminal space between 'reeducation' camps and private industry, proletarianisation and coerced labour. State documents note over and over that the new industrial parks are being built to instil an undefined 'basic quality' (基础素质) in Uyghur and Kazakh detainees and other Muslim surplus labourers. What is often left unsaid in state-approved documents is the way these factory spaces function as an archipelago of near total institutions at the periphery of the Chinese social contract-an implicit agreement that the state will protect its citizens in exchange for their loyalty. For Uyghurs and Kazakh Chinese citizens, this social contract has been shattered, as what Michel Foucault (1975) refers to as the prison archipelago is enlisted in a mode of colonial-capitalist production-a reeducation labour regime-that erodes the vitality of their indigenous social reproduction. The documents of the workers in Xinjiang's internment factories are confiscated or their IDs are marked as invalid, placing them under a pervasive form of unfreedom. This type of coerced labour is subsidised and directed by the state and operationalised by a complex web of surveillance practices and a logistics system that are bringing the Chinese factory to the Uyghur and Kazakh homelands. All this material development is authorised by the threatening presence of hundreds of internment camps that signify the power of the state over Turkic Muslim life.

Importantly, the effects of this system are not limited to northwestern China, or even to China itself. Nearly all the gloves made by detainees in the satellite factory of the Luye Shuozi Dao Trading Company are sold abroad. On the company's Alibaba distribution site, they note the price of their gloves ranges from US $\$ 1.50$ to US $\$ 24$ a pair depending on the style of the glove and quantity purchased. Some are distributed by the upscale Hong Kong-based boutique Bread n Butter, which has outlets in malls around the world where they likely are sold for far more. 
In any case, the price at which these gloves are sold is more than, at a minimum, exponentially higher than the price workers are paid per pair. This system of expropriation-a type of state-authorised theft-is justified by the rhetoric of charity, of 'aiding Xinjiang' (援疆) with the gift of the cultural capital provided by knowledge of Chinese language or framed as Han factory owners helping detainees to cultivate the 'quality' (素质) needed to be disciplined industrial workers (for a comparative study in Tibet, see Yeh 2013).

In an essay written in adulation of the internment factory complex, a Ghulja County official wrote that when the Turkic Muslim farmers and herders arrived at the factory, they 'took off their grass shoes, put on leather shoes, and became industrial workers' (Zero Distance Yining 2017). The counterfactual imagery of 'backward' (落后) minority people who wore primitive 'grass' (草) shoes being given the gift of factory discipline through internment precisely captures the spirit of the 'quality' acquisition process as seen by state workers and contractors. In a regional state media video valorising the implementation of a coercive job program, the reporter repeatedly noted that the Turkic Muslim workers did not even pause to look up at the camera during the filming (Ili Television 2018). The reporter interpreted this as a sign of their excellent work ethic as newly trained 'high-quality' workers. This discourse was also instilled by management. Both Yerzhan and Gulzira mentioned that their managers emphasised that they were making gloves for export, so the quality of their sewing had to be very high. The training they received in 'human quality' would be reflected in the quality of the gloves they mass produced.

The introduction of state-directed, Han-exclusive corporate power over Uyghur and Kazakh life has the effect of accelerating the alienating effects of factory labour across ethnic and class difference. Alienation, removing the individual from the ownership of their labour as workers and, in this case, from their autonomy as Turkic Muslim individuals, are in fact primary features of the reeducation factory. The goal of the reeducation industrial parks is to turn Kazakhs and Uyghurs into a deeply controlled proletariat, a newly docile yet productive lumpen class-those without the social welfare afforded to the formally recognised rights-bearing working class. By turning a population of people regarded as undeserving of legal protections into this permanent underclass, state authorities and private industrialists hope they will extend the market expansion of the Chinese textile and garment industry. They are building a colonial frontier in capitalist accumulation - a process that is simultaneously a new iteration 
of racialised capitalism and contemporary settler colonialism (Goldstein 2017; Byler 2018). This system of controlled labour is 'carried' (载体) forward by a massive reeducation system - a mechanism of infrastructural state power that ensures this new class of interned labourers cannot rise up as a class for themselves. In fact, because of this extralegal system, the only thing that protects Turkic Muslim workers from expropriation and violence is the good will of their Han managers. As indicated by the payment scheme at the glove factory, worker protections often appear as a form of 'investment' in the quality of Turkic workers even while worker wellbeing and indigenous social relationships are viewed as valueless.

\section{At the limit of global capitalism}

Since the factories function as an extension of the camp system, outside the rule of law and at the margin of the social contract, factory managers can treat Uyghur and Kazakh workers as disposable. In December 2018, managers at the factory threatened Gulzira with the prospect of being sent back to the camp if she did not sign a one-year work contract (Bunin 2019a). It was only because her husband in Kazakhstan began a campaign for her release-after she managed to text images of the factory to him and he spotted her in a state video promoting the industrial park-that local authorities reluctantly agreed to allow her to return to her family on the other side of the border. They were attempting to silence challenges to the 'aiding Xinjiang' narrative (see also Bunin 2019b). Yet, when these attempts failed, they cut their losses and let her go.

There is a nearly limitless standing reserve of other detainees who do not have advocates for them outside China. The archipelago of the reeducation labour regime continues out of sight-a ghostly presence at the end of global supply chains. In the race to the bottom-the least cost for the most productivity-the reeducation factory in Ghulja is at the limit of contemporary global capitalism. 
This text is taken from Xinjiang Year Zero, edited by Darren Byler, Ivan Franceschini and Nicholas Loubere, published 2022, The Australian National University, Canberra, Australia.

doi.org/10.22459/XYZ.2021.12 